\title{
CORTICOSTEROIDS - ASSETS AND LIABILITIES ON PERIODONTIUM
}

\author{
NADIMPALLI HARSHITA ${ }^{1}$, DEEPA G KAMATH ${ }^{2 *}$, SWATI $^{3}$ \\ Department of Periodontology, Manipal College of Dental Sciences, Manipal Academy of Higher Education, Mangalore, \\ Karnataka - 575 001, India. Email: deepa.gkamath@manipal.edu
}

Received: 06 April 2018, Revised and Accepted: 08 May 2018

\section{ABSTRACT}

Corticosteroids are chemically similar to endogenous cortisol and are used fundamentally as replacement therapy in patients with adrenal insufficiency, and used as anti-inflammatory agents. They are widely used in systemic diseases such as rheumatoid arthritis, asthma, and connective tissue disorders. In dentistry primarily these are used to decrease post-operative pain and edema in inflammatory diseases such as oral lichen planus, pemphigus, and recurrent aphthous stomatitis. This action is predominantly due to eicosanoid formation that inhibits phospholipase A2 activity. Corticosteroids can be supplemented either topically systemically or as inhalational therapy. Research suggests that local application of corticosteroids shows favorable effect on the periodontal ligament and possesses antiresorptive effect, but long-term systemic therapy is a risk for periodontal diseases which may provoke attachment loss and disruption of transseptal fibers. Oral manifestations are common with the use of inhaled steroids and are dependent on dose, frequency, duration, and inhaler use. It is commonly associated with ulceration of tongue, buccal mucosa, and occasionally on the gingiva due to xerostomia and immune suppression. It also causes a decrease in bone mineral density. This review explains about various effects of different types of corticosteroids on periodontium used in dentistry.

Keywords: Corticosteroids, Topical, Systemic, Inhalational, Bone mineral density, Periodontium.

(C) 2018 The Authors. Published by Innovare Academic Sciences Pvt Ltd. This is an open access article under the CC BY license (http://creativecommons. org/licenses/by/4. 0/) DOI: http://dx.doi.org/10.22159/ajpcr.2018.v11i8.25442

\section{INTRODUCTION}

Physiologically steroids (cortisol and aldosterone) are produced by adrenal glands and help in various physiological functions such as metabolism of fats, proteins and carbohydrates, immune mechanism, and salt water balance [1,2]. Testosterone, estrogen, cortisol, and aldosterone are the steroid hormones produced by the body [3]. Corticosteroids are synthetic analogs of steroid hormones that are produced in the adrenal cortex of vertebrates [4]. In situations where the endogenous production of steroids are impaired, they are required to be supplemented externally, however at physiological doses [5,6]. They are available in different formulations such as ointments, gels, and tablets $[7,8]$. Steroids were first used clinically to treat dermatological diseases due to their anti-inflammatory action. Corticosteroids are commonly indicated in treating various types of inflammatory and immune-mediated disorders such as adrenocortical insufficiency, rheumatic diseases [9], asthma, and skin diseases [10]. In dentistry, they are generally used to relieve pain, anxiety and for the management of oral lesions that are manifestations of systemic disorders [11]. Evidence for the use of corticosteroids in periodontology, is limited to its use for periodontal manifestations of systemic disorders, and not as a mode of treatment of periodontal disease per se. Nevertheless it is necessary to know the uses of corticosteroids in dentistry as well as the effect of their use on the periodontium, and thus is the aim of the present review [12]

\section{Uses of corticosteroids in dentistry}

Corticosteroids are commonly administered in the topical, systemic, and inhalational form [13]. Of these, topical corticosteroids are the ones which are commonly used for the treatment of oral lesions [14,15]. They have in fact evolved and emerged as the mainstay of therapy for numerous oral lesions and conditions such as oral lichen planus [16], erythema multiforme [17], desquamative gingivitis [18], and major aphthous ulcers [16]. Their use is due to mainly their anti-inflammatory, immunosuppressive, and anti-proliferative property [19]. These properties/actions are expressed as a result of a process called as transactivation, which induces anti-inflammatory proteins and regulatory proteins [20]. This process is mediated by the nuclear glucocorticoid receptors which are present in the cytoplasm and modulate transcription of proteins. Corticosteroids displace proteins like heat-shock proteins from the inactive receptor site and bind to the receptor, and this corticosteroid-receptor complex then translocates to the nucleus and bind to a specific sequence of deoxyriboNucleic Acid [21] (Fig. 1). The metabolic effects and some of the adverse drug reactions may occur through this process.

\section{Anti-inflammatory action}

This action is mainly brought about by topical corticosteroids which mainly function by inhibiting the formation of eicosanoids. Corticosteroids stimulate the production of various polypeptides, collectively called lipocortin which has inhibitory effects on phospholipase A2 activity [22]. They are also known to block the action of vasodilators such as histamine and bradykinin and leading to vasoconstriction. This is clinically evident by a reduction in erythema $[23,24]$.

\section{Immunosuppressant action}

This is brought about by suppression of cytokines namely interleukin 1 (IL - 1), IL- 2-6, IL-8, and tumor necrosis factor alpha, which results in a reduction of cell proliferation. They also affect the humoral immunity by reducing B cell expansion, antibody synthesis, and destruction of $\mathrm{T}$ lymphocytes [25].

\section{Anti-proliferative action}

This is seen as a result of a reduction in the mitosis in the epidermis which makes the basal cell layer thin, along with the stratum corneum and granulosum. Keratinocyte proliferation is seen to be affected, a decrease in the keratinocyte growth factor is noted, and also there is inhibition of fibroblast proliferation, migration, and chemotaxis. As these processes continue, abnormal aggregation of the elastin and collagen fibers becomes evident, thereby decreasing the synthesis of collagen and glycosaminoglycan's [26].

Topical corticosteroids are the most common form that is used for oral lesions, and hence it is important to know the factors that need to be taken into account when prescribing or using them. The effectiveness 


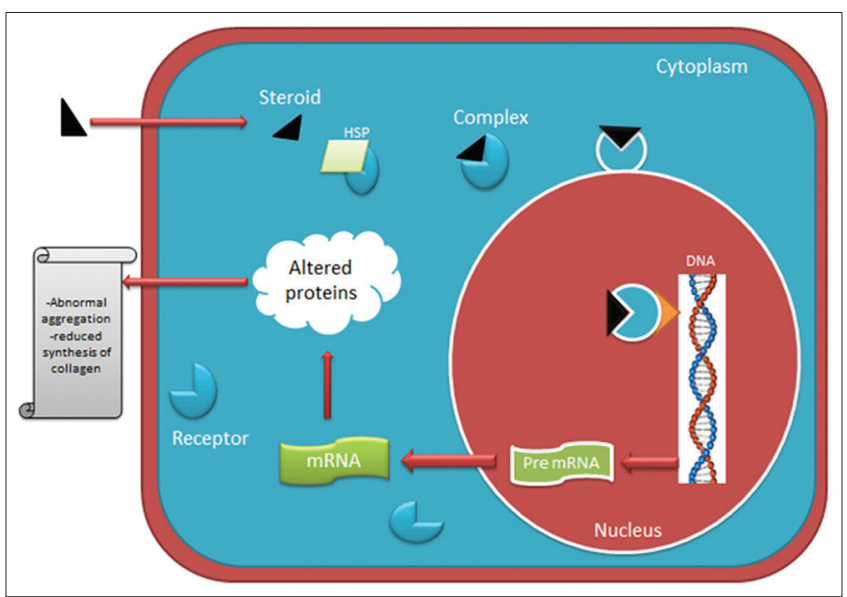

Fig. 1: Mechanism of action at molecular level (mRNA - messenger Ribose nucleic acid)

of treatment with topical corticosteroids depends on the halogenation of its main ingredient, i.e., cortisol. This halogenation leads to increased binding of cortisol to the glucocorticoid receptor. The penetration of the topical corticosteroid depends on the esterification of cortisol which increases the lipophilicity of the steroid [27]. Hence, the selection of corticosteroids should be based mainly on the potency of drug and area of application [28]. There are various classifications of topical corticosteroids based on their potency with or without using the vehicle. Among them, World health organization (WHO) classifies the topical corticosteroids into seven classes/groups, with Group 1 being the most potent and Group 7 being the least potent. In this system, potency is based on the activity of topical corticosteroid molecule, its concentration, and nature of vehicle [29]. The high potency formulations are recommended for short-term use only and are required for areas such as palms and soles and also for chronic or hyperkeratotic lesions. Low to medium potency topical corticosteroids are useful for acute inflammatory lesions on the face and can be used for a long-term [30]. Normally, high potency steroids for short-term duration are used for the oral application. Common corticosteroids used in dentistry based on their potency are listed in Table.1.

Topical corticosteroids are available in many formulations: Creams, ointments, lotions, and gel/hydrogel [31,32]. Vehicles function as a carrier for the active topical corticosteroid molecule, hydrate the skin and may help to increase the drug penetration. The absorption and potency of drug depend on the vehicle used, in addition to the chemical structure of the corticosteroid molecule [33]. Creams are water-based formulations and have a low occlusive ability. They spread easily, without a greasy feel, and is thus preferred by the patients [34]. Ointments are preferred for dry or scaly lesions and in highly keratinized areas. They increase hydration and provide good occlusion, thus improving drug penetration. Drug action can be enhanced further by the addition of propylene glycol, which increases the solubility of the drug in the vehicle. Among adhesive ointments, the orabase ointment (triamcinolone acetonide) is one of the most commonly used. It is a commercial formula that does not contain analgesics or antibiotics. Gels are formulated with a gelling agent and offer ease of application, but they are rarely used due to the possibility of causing pain after being applied. Conventionally, ointments have been considered to be more potent than the rest of the formulations [35].

The use of corticosteroids for treatment of periodontal disease is limited. Corticosteroids are known to have an effect on fibroblasts and bone remodeling [19], which may affect the periodontium and hence it is important to know about the uses and side effects of corticosteroids on the periodontium.
Effect of corticosteroids use on periodontium

The uses of corticosteroids solely for periodontal purposes are rare; hence, we have here tried to list out the possible effects of corticosteroid use on the periodontium (either in topical, inhalational or systemic form). The possible adverse effects of each type of corticosteroids are highlighted.

In periodontology, topical and systemic steroids have been indicated for patients with dermatologic disorders, such as pemphigus, erythema multiforme, and systemic lupus erythematoses which have shown any gingival or periodontal manifestation.

\section{Topical corticosteroids}

Corticosteroids, when applied topically on inflamed marginal gingiva with periodontal disease, have shown a reduction of bleeding and inflammation without affecting the periodontal disease progression [36]. Histologically, reduction in capillary permeability, a decrease in plasma cells and granulation tissue, and inhibition of collagen formation is noted when corticosteroids are injected into the gingiva [36-38]. Although not conclusive, reports exist, which indicate the antiresorptive action of corticosteroids [39]. In an in vitro study, when the effect of dexamethasone (Dex) on osteoblasts was studied for 21 days, it was noted that Dex affects directly the formation of osteoclasts by altering the proliferation and differentiation of osteoclasts precursors and inhibiting bone resorption in mature osteoclasts. It also helps in osteoblastic differentiation from gingival fibroblasts by regulating the expression of Runt-related transcription factor 2 (Runx2) [40,41]. Runx2 also known as core-binding factor subunit alpha-1 is a protein that in humans is encoded by the Runx2 gene and is a key transcription factor associated with osteoblast differentiation [42]. Studies have also demonstrated a concentration-dependent effect of corticosteroids. It was shown that hydrocortisone at high concentration $\left(10^{7}\right)$ increase matrix metalloproteinases (MMP) levels (MMP1, MMP2, MMP7, and MMP11), whereas at low concentration $\left(10^{9}\right)$ it downregulates their expression. Hence, studies using different doses of drugs and their effects on periodontal tissue are required to prove the clinical efficacy of these drugs [43].

Furthermore, the oral lesions that are treated by corticosteroids being chronic in nature, requires the drug to be in constant contact with the area being targeted for treatment. The use of a tray designed for the same, allows for the drug to be secure and also provides for an occlusive therapy $[44,45]$.

\section{Systemic corticosteroids}

Animal studies have shown that systemic steroids have adverse effects on the periodontium and its response to bacterial plaque. These studies have reported a change in response of plaque after steroid supplementation [46]. However, studies done on humans have shown that the reaction on gingival tissues was more related to the oral hygiene status and the age of the individual than to "whether or not the patient had been receiving steroids." This observation was further validated by experimental studies which have reported that use of systemic corticosteroids for more than 6 months can affect the periodontium [47]. It is initially seen as gingival ulceration, which may progress to the apical migration of the epithelium, leading to loss of transseptal fibers and attachment loss [48,49]. Data from animal experiments and observations in humans have demonstrated that the systemic corticosteroids may result in increased osteoporosis of alveolar bone due to increase in serum levels of corticosteroids, which may be a risk factor of periodontal disease [50-52]. Corticosteroids have a significant effect on bone metabolism. They increase bone resorption, inhibit bone formation, decrease the intestinal absorption of calcium ions and modify Vitamin D metabolism [53]. Olgaard et al., in 1992, have stated that although significant reductions of the bone mineral content were observed in corticosteroid treated-nephrotic patients and that the bone decay rates were significantly different at the mandible, forearm, and lumbar spine [54]. A study comparing the 
Table 1: Commonly used corticosteroids in dentistry

\begin{tabular}{|c|c|c|c|}
\hline Potency & Examples & Concentration & Lesions \\
\hline Ultrahigh & Clobetasol propionate & Cream, $0.05 \%$ & $\begin{array}{l}\text { Oral lesions of psoriasis (rare), vesiculobullous lesions, } \\
\text { desquamative gingivitis }\end{array}$ \\
\hline High & $\begin{array}{l}\text { Betamethasone } \\
\text { dipropionate } \\
\text { fluocinonide } \\
\text { triamcinolone } \\
\text { acetonide }\end{array}$ & $\begin{array}{l}\text { Ointment, } 0.05 \% \text { cream, or gel, } \\
0.05 \% \text { ointment, } 0.1 \%\end{array}$ & $\begin{array}{l}\text { Oral lichen planus aphthous ulcers lichen planus, } \\
\text { traumatic ulcers }\end{array}$ \\
\hline Moderate & $\begin{array}{l}\text { Fluocinolone } \\
\text { acetonide } \\
\text { triamcinolone } \\
\text { acetonide }\end{array}$ & Ointment, $0.025 \%$ cream, $0.1 \%$ & Pemphigus lichen planus \\
\hline Low & $\begin{array}{l}\text { Dex sodium } \\
\text { phosphate } \\
\text { methylprednisolone }\end{array}$ & $\begin{array}{l}\text { Oral } \\
\text { Oral }\end{array}$ & Perioperative use in dentoalveolar surgeries \\
\hline
\end{tabular}

Dex: Dexamethasone

use of two different corticosteroid drugs and their effect on bone has shown that the detrimental effect of long-term steroid treatment on the skeleton may not be abolished, but it can be reduced significantly by using deflazacort when compared to prednisone [55]. A recent in vitro study showed the effect of Dex on periodontal ligament stem cells (PDLSCs), induces many genes, including dickkopf-1 (DKK-1) in PDLSCs. Enzyme-linked immunosorbent assay showed that DKK-1 is secreted from PDLSCs in response to dexamethasone (Dex) treatment in human PLDSCs this induced DKK-1 wingless-type MMTV (mouse mammary tumor virus) integration site (Wnt) - mediated activation of $\beta$-catenin signaling and inhibits the growth of PDLSCs thereby causing increase in periodontal breakdown [56]. In contrast, few studies have shown no significant difference in periodontal parameters with the long-term use of corticosteroids [57]. In a study done in patients having neurological disorders who were on corticosteroid therapy had, no difference in periodontal parameters in follow-up period of 1-4 years was observed $[58,59]$. It has been shown that long-term administration of systemic corticosteroids may lead to adrenal suppression, immunosuppression, central obesity, hyperglycemia, and increased susceptibility to infection, reduction of bone mineral density (BMD), and increased risk of osteoporosis [60-62].

\section{Inhalational corticosteroids}

Inhalational corticosteroids are not used for the treatment for oral lesions; however, their use for the treatment of respiratory diseases is not without side effects. Although these medications, are generally, considered safer when compared to oral and systemic corticosteroids, they also have adverse effects [63]. Inhalational corticosteroids are generally prescribed in asthmatic patients. In this group of patients, the salivary flow and the concentration of immunoglobulin $\mathrm{A}$ is reduced; there is dehydration of alveolar mucosa due to mouth breathing, alteration of immune response and an increase in the concentration of immunoglobulin $\mathrm{E}$ in gingival tissue. A higher incidence of calculus formation in these patients is observed, due to increased levels of calcium and phosphorous in saliva, contributing to the poor periodontal health in these patients $[64,65]$. When inhalational corticosteroids are administered to these patients, in addition to the above-mentioned effects, an increase in periodontal destruction is observed, and also changes in the BMD are noted. Current evidence suggests that in adults, systemic effects of inhalational corticosteroids do not lead to adverse effects at doses of $400 \mu \mathrm{g}$ or less of budesonide [66].

It has been suggested that the type of inhaler used for administering corticosteroids should also be taken into consideration $[67,68]$. Inhalers are available with or without a spacer attached, and it is reported that spacer devices attached to inhalers can reduce the local effects of the steroids when compared to those without spacers $[69,70]$. Literature presents with systematic reviews and meta-analyses which have examined the effect of inhaled corticosteroids on BMD, the conclusions derived however differed considerably [71]. For example, Leone et al., in 2003, concluded that adult asthma patients generally do not sustain a significant reduction in BMD in response to inhaled corticosteroid treatment [72], whereas Richy et al. 2003 concluded that all inhaled corticosteroids affect BMD. It is also unclear, whether a threshold dose for adverse effects exists [73]. The main effects are seen with doses above $1600 \mathrm{~g}$ [74]. Tooth loss as a result of decreased BMD has been observed in asthmatic patients undergoing long-term inhalational steroid therapy $[75,76]$. This reduced BMD was evident in the mandible, and it could be because of fractions of drug remaining in the oral cavity [77]. It is thus suggested that patients on inhalational corticosteroids should have their mandibular BMD checked regularly, especially if they have any risk factors for osteoporosis [78,79]. A reduction of the dose of inhalational corticosteroids has also been suggested in these patients. An increase in the risk of caries, gingival inflammation and reduced salivary secretion is also seen in young adult patients on long-term steroid therapy. The severity and incidence of severe gingivitis are more in patients using inhalational corticosteroids than other forms of steroids. It has been suggested that the inhalers used and mouth breathing may lead to decreased saliva production, changes in $\mathrm{pH}$, and increased risk of plaque and caries $[80,81]$. However, animal studies have shown that inhaled budesonide does not modulate periodontal breakdown. This might be due to inappropriate formulation and dosage. Additional studies are needed to estimate the effects of budesonide on the oral mucosa and the periodontium.

\section{CONCLUSION}

Wide applications of corticosteroids in dentistry can be mainly owed to their excellent anti-inflammatory and immunomodulatory properties. Patients with gingival lesions of vesiculobullous diseases require interdisciplinary care, and the form of application will be depended on various factors that have to be considered. Along with the important role in the management of lesions affecting the oral mucosa and skin, these agents also carries the potential side effects that are sometimes very severe. One question that remains is whether the risk of adverse effects on bone differs among the different corticosteroids. The reasons for these inconsistent findings may be due to insufficient dosage and inadequate interactions among the combination of drugs taken by the patient. Although these drugs have good anti-inflammatory and immunosuppressive properties, corticosteroids are less used in the management of periodontal diseases.

\section{ACKNOWLEDGMENTS}

Nil.

\section{AUTHOR'S CONTRIBUTION}

Writing the article - Nadimpalli Harshita. Corrections and final approval of the article - Deepa G Kamath and Swati Pralhad. 


\section{CONFLICTS OF INTEREST}

Nil.

\section{REFERENCES}

1. Sweetman SC. Martindale: The Complete Drug Reference. $37^{\text {th }}$ ed. London: Pharmaceutical Press; 2011.

2. Bruton LL, Lazo JS, Parker KL. Goodman and Gilman'S the Pharmacological Basis of Therapeutics. 11 ${ }^{\text {th }}$ ed. New York: McGrawHill; 2006.

3. Loose DS, Stancel GM. Estrogens and progestins. In: Brunton LL, Lazo JS, Parker KL editors. Goodman and Gilmans the Pharmacological Basis of Therapeutics. 11 th ed. New York: McGraw-Hill; 2006. p. 1541-72.

4. Ganong WF. Review of Medical Physiology. $24^{\text {th }}$ ed. China: LANGE Basic Science; 2012.

5. Bennett PN, Brown MJ. Clinical Pharmacology. $9^{\text {th }}$ ed. New Delhi: Reed Elsevier; 2003. p. 664

6. Ata-Ali J, Ata-Ali F, Peñarrocha-Oltra D, Peñarrocha M. Corticosteroids use in controlling pain, swelling and trismus after lower third molar surgery. J Clin Exp Dent 2011;3:469-75.

7. Lozada-Nur F, Miranda C, Maliksi R. Double-bind clinical trial of $0.05 \%$ clobetasol proprionate ointment in orabase and $0.05 \%$ fluocinonide ointment in orabase in the treatment of patients with oral vesiculoerosive diseases. Oral Surg Oral Med Oral Pathol 1994;77:598-604.

8. Lozada F, Silverman S Jr. Topically applied fluocinonide in an adhesive base in the treatment of oral vesiculoerosive diseases. Arch Dermatol 1980; $116: 898-900$

9. Tanya Syngle, Sudeep Kaur, Nidhi Garg. Osteoporotic fracture risk in rheumatoid arthritis Int J Pharm Pharm Sci 2018;10:106-9.

10. McGraw-Hill. Concise Encyclopedia of Bioscience. $1^{\text {st }}$ ed. New York: McGraw-Hill Publishing; 2004.

11. Baxendale BR, Vater M, Lavery KM. Dexamethasone reduces pain and swelling following extraction of third molar teeth. Anaesthesia 1993;48:961-4.

12. Glick MS, Greenberg M, Ship JA. Burket's Oral Medicine. $11^{\text {th }}$ ed. Hamilton, BC: Decker Inc; 2008

13. Grover VK, Babu R, Bedi SP. Steroid therapy current indications in practice. Int Jugglers' Assoc 2007;51:339-89.

14. Voûte AB, Schulten EA, Langendijk PN, Kostense PJ, van der Waal I. Fluocinonide in an adhesive base for treatment of oral lichen planus. A double-blind, placebo-controlled clinical study. Oral Surg Oral Med Oral Pathol 1993;75:181-5.

15. Lozada-Nur F, Huang MZ. Open preliminary clinical trial of clobetasol propionate in adhesive paste for treatment of chronic oral vesiculoerosive diseases. Oral Surg Oral Med Oral Pathol 1991;71:283-7.

16. Altenburg A, Zouboulis CC. Current concepts in the treatment of recurrent aphthous stomatitis. Skin Therapy Lett 2008;13:13-4.

17. Sai Keerthana PC, Anila KN, Reshma Reji. Naproxen-induced erythema multiforme-a rare case report. Int J Pharm Pharm Sci 2017;9:294-5

18. Gonzalez-Moles MA, Morales P, Rodriguez-Archilla A, Isabel IR, Gonzalez-Moles S. Treatment of severe chronic oral erosive lesions with clobetasol propionate in aqueous solution. Oral Surg Oral Med Oral Pathol Oral Radiol Endod 2002;93:264-70.

19. Seymour RA, Heasman PA. Drugs and the periodontium. J Clin Periodontol 1988;15:1-6.

20. McMaster A, Ray DW. Drug insight: Selective agonists and antagonists of the glucocorticoid receptor. Nat Clin Pract Endocrinol Metab 2008;4:91-101.

21. Schimmer BP, Funder WH. ACTH, adrenal steroids, and pharmacology of the adrenal cortex. In: Brunton LL, editor. Pharmacological Basis of Therapeutics. $13^{\text {th }}$ ed. New York, NY: McGraw-Hill; 2011. p. 1209-36.

22. Hirata F, Schiffmann E, Venkatasubramanian K. A phospholipase A2 inhibitory protein in rabbit neutrophils induced by glucocorticoids. Proc Natl Acad Sci U S A 1980;77:2533-6.

23. Burkholder B. Topical corticosteroids: An update. Curr Probl Dermatol 2000;12:222-5.

24. Mori M, Pimpinelli N, Giannotti B. Topical corticosteroids and unwanted local effects. Improving the benefit/risk ratio. Drug Saf 1994;10:406-12.

25. Leung DY, Bloom JW. Update on glucocorticoid action and resistance. J Allergy Clin Immunology 2003;111:3-22.

26. Hein R, Krieg T. Effects of corticosteroids on human fibroblasts in-vitro. In: Chrostophers E, Schopf E, Kligman AM, Schopf E, Stoughton RB, editors. Topical Corticosteroid Therapy: A Novel Approach to Safer
Drugs. New York, NY: Raven Press; 1988. p. 57-65.

27. Katz M, Gans EH. Topical corticosteroids, structure-activity and the glucocorticoid receptor: Discovery and development-a process of "planned serendipity". J Pharm Sci 2008;97:2936-47.

28. Drake LA, Dinehart SM, Farmer ER, Goltz RW, Graham GF, Hordinsky MK, et al. Guidelines of care for the use of topical glucocorticosteroids. American academy of dermatology. J Am Acad Dermatol 1996;35:615-9

29. WHO model prescribing information: drugs used in skin diseases: Annex: Classification of topical corticosteroids. [Internet] [Cited 2017 Jan 13].

30. Community Drug Utilization Program: Topical Corticosteroids. Saskatchewan Health, Saskatoon; 1998

31. Zegarelli EV, Kutscher AH, Mehrhof A. Long-lasting loz-enges with triamcinolone acetonide. Treatment of erosive li-chen planus of oral mucosa. N Y State J Med 1969;69:2463-4.

32. Hegarty AM, Hodgson TA, Lewsey JD, Porter SR. Fluti-casone propionate spray and betamethasone sodium phos-phate mouthrinse: A randomized crossover study for the treatment of symptomatic oral lichen planus. J Am Acad Dermatol 2002;47:271-9.

33. Yohn JJ, Weston WL. Topical glucocorticosteroids. Curr Probl Dermatol 1990;2:31-63.

34. Buttgereit F, Saag KG, Cutolo M, da Silva JA, Bijlsma JW. The molecular basis for the effectiveness, toxicity, and resistance to glucocorticoids: Focus on the treatment of rheumatoid arthritis. Scand J Rheumatol 2005;34:14-21.

35. Lee NP, Arriola ER. Topical corticosteroids: Back to basics. West J Med 1999;171:351-3.

36. Berliner DL, Nabors CJ Jr. Effects of corticosteroids on fibroblast functions. J Reticuloendothel Soc 1967;4:284-313.

37. Bauer EA, Kronberger A, Valle KJ, Jeffrey JJ, Eisen AZ. Glucocorticoid modulation of collagenase expression in human skin fibroblast cultures. Evidence for pre-translational inhibition. Biochim Biophys Acta 1985;825:227-35

38. Priestley GC, Brown JC. Effects of corticosteroids on the proliferation of normal and abnormal human connective tissue cells. Br J Dermatol 1980;102:35-41.

39. Kirakozova A, Texeira F, Curran A, Gu, F, Tawil P, Trope M. Effect of intracanal corticosteroids on healing of replanted dog teeth after extended dry times. J Appl End 2009;35:663-7.

40. Hamidouche Z, Haÿ E, Vaudin P, Charbord P, Schüle R, Marie PJ, et al. FHL2 mediates dexamethasone-induced mesenchymal cell differentiation into osteoblasts by activating wnt/beta-catenin signalingdependent runx2 expression. FASEB J 2008;22:3813-22.

41. Langenbach F, Handschel J. Effects of dexamethasone, ascorbic acid and b-glycerophosphate on the osteogenic differentiation of stem cells in vitro. Stem Cell Res Ther 2013;4:117-23.

42. Hirayama T, Sabokbar A, Athanasou AN. Effect of corticosteroids on human osteoclast formation and activity. J Endoc 2002;175:155-63.

43. Cury PR, Araújo VC, Canavez F, Furuse C, Araújo NS. Hydrocortisone affects the expression of matrix metalloproteinases (MMP-1, -2, -3, -7, and -11) and tissue inhibitor of matrix metalloproteinases (TIMP-1) in human gingival fibroblasts. J Periodontol 2007;78:1309-15.

44. Aufdemorte TB, De Villez RL, Parel SM. Modified topical steroid therapy for the treatment of oral mucous membrane pemphigoid. Oral Surg Oral Med Oral Pathol 1985;59:256-60.

45. Gonzalez-Moles MA, Ruiz-Avila I, Rodriguez-Archilla A, MoralesGarcia P, Mesa-Aguado F, Bascones-Martinez A, et al. Treatment of severe erosive gingival lesions by topical application of clobetasol propionate in custom trays. Oral Surg Oral Med Oral Pathol Oral Radiol Endod 2003;95:688-92.

46. Seymour AR. Effects of medications on the periodontal tissues in health and disease. Periodontol 2000 2006;40:120-9.

47. Labelle RE, Schaffer EM. The effects of cortisone and induced local factors on the periodontium of the albino rat. J Periodontol 1966;37:483-90.

48. Garsia GV, Fernandes AL, Almeida MJ, Bosco FA, Hitomi JM. Comparison between laser therapy and non-surgical therapy for periodontitis in rats treated with dexamethasone. Las Med Sci 2010;25:197-206.

49. Drozdzowska B, Pluskiewicz W, Michno M. Tooth count in elderly women in relation to their skeletal status. Maturitas 2006;55:126-31.

50. Nicopoulou-Karayianni K, Tzoutzoukos P, Mitsea A, Karayiannis A, Tsiklakis K, Jacobs R, et al. Tooth loss and osteoporosis: The OSTEODENT Study. J Clin Periodontol 2009;36:190-7.

51. Kribbs PJ. Comparison of mandibular bone in normal and osteoporotic women. J Prosthet Dent 1990;63:218-22. 
52. Krall EA, Garcia RI, Dawson-Hughes B. Increased risk of tooth loss is related to bone loss at the whole body, hip, and spine. Calcif Tissue Int 1996;59:433-7.

53. Lukert BP, Adams JS. Calcium and phosphorus homeostasis in man. Effect of corticosteroids. Arch Intern Med 1976;136:1249-53.

54. Olgaard K, Storm T, van Wowern N, Daugaard H, Egfjord M, Lewin E, et al. Glucocorticoid-induced osteoporosis in the lumbar spine, forearm, and mandible of nephrotic patients: A double-blind study on the highdose, long-term effects of prednisone versus deflazacort. Calcif Tissue Int 1992;50:490-7.

55. Gray RE, Doherty SM, Galloway J, Coulton L, de Broe M, Kanis JA, et al. A double-blind study of deflazacort and prednisone in patients with chronic inflammatory disorders. Arthritis Rheum 1991;34:287-95.

56. Krishnan V, Bryant HU, Macdougald OA. Regulation of bone mass by wnt signaling. J Clin Invest 2006;116:1202-9.

57. Choi SS, Park EK, Kwack MH, Sung YK. Effects of dexamethasone, a synthetic glucocorticoid, on human periodontal ligament stem cells Naunyn Schmiedebergs Arch Pharmacol 2015;388:991-95.

58. Safkan B, Knuuttila M. Corticosteroid therapy and periodontal disease. J Clin Periodontol 1984;11:515-22.

59. Bonadonna S, Burattin A, Nuzzo M, Bugari G, Rosei EA, Valle D, et al. Chronic glucocorticoid treatment alters spontaneous pulsatile parathyroid hormone secretory dynamics in human subjects. Eur J Endocrinol 2005;152:199-205.

60. Ohnaka K, Taniguchi H, Kawate H, Nawata H, Takayanagi R. Glucocorticoid enhances the expression of dickkopf-1 in human osteoblasts: Novel mechanism of glucocorticoid- induced osteoporosis. Biochem Biophys Res Commun 2004;318:259-64.

61. Ebeling PR, Erbas B, Hopper JL, Wark JD, Rubinfeld AR. Bone mineral density and bone turnover in asthmatics treated with long-term inhaled or oral glucocorticoids. J Bone Miner Res 1998;13:1283-9.

62. Azarpazhooh A, Leake JL. Systematic review of the association between respiratory diseases and oral health. J Periodontol 2006;77:1465-82.

63. Roland NJ, Bhalla RK, Earis J. The local side effects of inhaled corticosteroids: Current understanding and review of the literature. Chest 2004;126:213-9.

64. Shashikiran ND, Reddy VV, Raju PK. Effect of antiasthmatic medication on dental disease: Dental caries and periodontal disease. J Indian Soc Pedod Prev Dent 2007;25:65-8.

65. Dyer MJ, Halpin DM, Stein K. Inhaled ciclesonide versus inhaled budesonide or inhaled beclomethasone or inhaled fluticasone for chronic asthma in adults: A systematic review. BMC Fam Pract 2006;7:34.

66. Pauwels R, Newman S, Borgstrom L. Airway deposition and airway effects of antiasthma drugs delivered from metereddose inhalers. Eur Respir J 1997;10:2127-38.

67. Anderson PJ. Delivery options and devices for aerosolized therapeutics.
Chest 2001;120:89S-93S.

68. Bernstein DI, Berkowitz RB, Chervinsky P, Dvorin DJ, Finn AF, Gross GN, et al. Dose-ranging study of a new steroid for asthma: Mometasone furoate dry powder inhaler. Respir Med 1999;93:603-12.

69. Toogood JH, White FA, Baskerville JC, Fraher LJ, Jennings B. Comparison of the antiasthmatic, oropharyngeal, and systemic glucocorticoid effects of budesonide administered through a pressurized aerosol plus spacer or the turbuhaler dry powder inhaler. J Allergy Clin Immunol 1997;99:186-93.

70. Jones A, Fay JK, Burr M. Inhaled corticosteroid effects on bone metabolism in asthma and mild chronic obstructive pulmonary disease (Cochrane Review) Update Software. Issue 3. Oxford, UK: The Cochrane Library; 2003.

71. Leone FT, Fish JE, Szefler SJ, West SL. Systematic review of the evidence regarding potential complications of inhaled corticosteroid use in asthma: Collaboration of American college of chest physicians, American academy of allergy, asthma, and immunology, and American college of allergy, asthma, and immunology. Chest 2003;124:2329-40.

72. Richy F, Bousquet J, Ehrlich GE, Meunier PJ, Israel E, Morii H, et al. Inhaled corticosteroids effects on bone in asthmatic and COPD patients: A quantitative systematic review. Osteoporos Int 2003;14:179-90.

73. Hubbard RB, Smith CJ, Smeeth L, Harrison TW, Tattersfield AE. Inhaled corticosteroids and hip fracture: A population-based casecontrol study. Am J Respir Crit Care Med 2002;166:1563-6.

74. Van Staa TP, Leufkens HG, Cooper C. Use of inhaled corticosteroids and risk of fractures. J Bone Miner Res 2001;16:581-8.

75. Martin RJ, Szefler SJ, Chinchilli VM. Systemic effect comparisons of six inhaled corticosteroid preparations. Am J Respir Crit Care Med 2002; $165: 1377-83$

76. Derendorf H. Pharmacokinetic and pharmacodynamic properties of inhaled corticosteroids in relation to efficacy and safety. Respir Med 1997;91:22-8

77. Selroos O, Halme M. Effect of a volumatic spacer and mouth rinsing on systemic absorption of inhaled corticosteroids from a metered dose inhaler and dry powder inhaler. Thorax 1991;46:891-4.

78. El O, Gulbahar S, Ceylan E. Bone mineral density in asthmaticpatients using low dose inhaled glucocorticosteroids. J Investig Allergol Clin Immunol 2005; 15:57-62.

79. Jones A, Fay JK, Burr M. Inhaled corticosteroid effects on bone metabolism in asthma and mild chronic obstructive pulmonary disease. Cochrane Database Syst Rev 2002;1:CD003537.

80. Boskabady M, Nematollahi H, Boskabady $\mathrm{MH}$. Effect of inhaled medication and inhalation technique on dental caries in asthmatic patients. Iran Red Crescent Med J 2012;14:816-21

81. Daudt DL, Cavagni J, Gaio JE, Souza A. Torres SL, Ferreira AP, et al. Effect of inhaled corticosteroid on TNF- $\alpha$ production and alveolar bone loss in Wistar rats. Arch Oral Biol 2011;56:1398-403. 